\title{
Health literacy in the urban health infrastructure: who maintains healthcare and how
}

\author{
Elena Nekhorosheva $^{1 *}$, Leonid Denisov ${ }^{1}$, Elena Alekseycheva ${ }^{2}$, and Daria Kasatkina ${ }^{1}$ \\ ${ }^{1}$ Moscow City University, Laboratory of Personality Development and Health Protection, Moscow, \\ Russia \\ ${ }^{2}$ Moscow City University, All-university Department of Philosophy and Social Sciences, Moscow, \\ Russia
}

\begin{abstract}
Today we may witness a dire need to research how the urban environment influences urban health, well-being, and sustainability of local communities. The issue of urban health is closely connected with disease prevention projects and the integration of new preventive medical approaches with educational technologies. Due to a large number of responsible parties for the development of health literacy under the authority of different establishments, there is a problem to coordinate aligned activities. Thus the research of the healthcare institutions actions in health literacy development is extremely relevant. The objective of this research is to carry out an integral assessment of the degree to which the functions of preventing non-communicable diseases and developing health literacy are fulfilled by the sectors responsible for urban healthcare. The methods used in this research include a two-phase expert survey: the first group of experts (n: 24) selected the key aspects of healthcare activities, and the second group of experts (n: 35) assessed the quality of implementation of tasks by institutions in charge of disease prevention. The major problem is the lack of effective communication mechanisms in the sphere of intersectoral cooperation, informing the key disease prevention bodies of distributed responsibility, as well as state and social control of execution of laws and regulations. According to the obtained results, the state healthcare system is an important component of the health infrastructure. The functions connected with meeting the vital needs of the city population received medium-high ratings. However, the implementation of disease prevention functions by the healthcare system in Moscow was rated by experts at a low level. Besides, the experts consistently assigned an extremely low rating to the development of health literacy as one of the areas of activity covered by all sectors. To reinforce their outreach and awareness-raising work in the sphere of healthcare, executors of federal projects have to incorporate educational activities into their daily work.
\end{abstract}

Keywords: health literacy, healthcare, health infrastructure, urban health.

${ }^{*}$ Corresponding author: sjelene@yandex.ru 


\section{Introduction}

Despite a large number of institutions in charge of the formation of health literacy, society addresses the greatest expectations in this relation to education. Indeed, while performing an important academic function, the education system pursues and balances various educational purposes, including the opportunities to develop healthy habits incorporated in the educational program, such as healthy eating, physical exercise, and self-regulation training. Practice shows that the effectiveness of educational activity in the sphere of health largely depends on cooperation between educational structures and external partners responsible for the formation of health literacy. Society is trying to create conditions that would allow everyone to keep healthy. Therefore, it places focus on cooperation between different sectors and integration of resources to reach the goals in the sphere of health [1]. As an integrator of city resources, school is an open system incorporated in urban social infrastructure, including the disease prevention and health literacy formation infrastructure [2].

Joint partnerships (people or organizations from different sectors working together to accomplish a common goal) represent an important strategy aimed at the health improvement of the population. Collaborations have an impact on the changes taking place in society and systems (changes of the environment), behavior changes involving the whole community, and long-term results in terms of population health [3,4].

It should be noted that such collaboration is characterized by an industry-based approach to problem-solving, conflicts of interests, competition for resources, and poor communications. Attempts at the organization of interdepartmental cooperation are of nominative character, joint "networking" tasks raise criticism on the part of parents, and distributed responsibility turns into sole responsibility of school for children's health. In this connection, it is relevant to look for new forms of joint organization for implementation of the legislator's intention to create a sustainable disease prevention infrastructure [5]. In light of the modern trend towards a healthy lifestyle in the Moscow megacity, this is true for the whole urban space.

The objective of this research is to specify and describe the functioning of disease prevention infrastructure from the perspective of accomplishment of goals by each structure responsible for health and development of health literacy, assess the quality of prevention activities within the education system in cooperation with other structures, the potential for the development of certain lines of activity, and problem areas of the cooperation, and evaluate the effectiveness of the existing system of health literacy formation.

\section{Methods}

A two-phase expert survey. During the first phase, as a result of ranking carried out by experts (n: 24), the key aspects of healthcare activities conducted in the framework of institutionalized educational initiatives were selected (Table 1). The second group of experts (n: 35 ) assessed the quality of implementation of tasks by each institution in charge of disease prevention. Processing of expert evaluations included an assessment of the consistency of opinions (variation coefficient).

\section{Results}

Based on the expert evaluation results, the quality of implementation of functions is reflected in four groups: the first group - medium-high values (3.8-4.3), the second group - medium values (3.3-3.8), the third group - medium-low values (2.8-3.3), and the fourth group - low values $(2.3-2.8)$. High values were not assigned to any of the functions (Table 1$)$. 
Table 1. Weighted average values of expert ratings.

\begin{tabular}{|c|c|c|}
\hline Function & Institution & $\begin{array}{c}\text { Valu } \\
\text { e }\end{array}$ \\
\hline Rendering emergency medical assistance & Accident and emergency department & 4.11 \\
\hline Case investigation & Rospotrebnadzor & 4.03 \\
\hline Creating safe conditions & School & 3.97 \\
\hline $\begin{array}{l}\text { Control and compliance with health } \\
\text { legislation }\end{array}$ & Rospotrebnadzor & 3.89 \\
\hline Preventive vaccination & Children's municipal polyclinic & 3.89 \\
\hline Rendering specialized medical care & Clinics & 3.83 \\
\hline $\begin{array}{l}\text { Control of sanitary and hygienic learning } \\
\text { conditions }\end{array}$ & Rospotrebnadzor & 3.8 \\
\hline Rendering primary healthcare & Children's municipal polyclinic & 3.8 \\
\hline Urban landscaping around schools & Local self-government authorities & 3.74 \\
\hline Delivering healthcare services & $\begin{array}{l}\text { Nongovernmental healthcare } \\
\text { organizations }\end{array}$ & 3.71 \\
\hline Educational and research projects & Moscow City Pedagogical University & 3.69 \\
\hline $\begin{array}{l}\text { Social demand for a safe learning } \\
\text { environment }\end{array}$ & Family & 3.66 \\
\hline Ready for labor and defense & Sphere of physical training and sports & 3.54 \\
\hline Social-hygienic monitoring & Rospotrebnadzor & 3.46 \\
\hline Preventive medical examination and check-up & Children's municipal polyclinic & 3.46 \\
\hline $\begin{array}{l}\text { Maintenance of the activities held by medical } \\
\text { classes }\end{array}$ & $\begin{array}{l}\text { Medical education and research } \\
\text { organizations }\end{array}$ & 3.43 \\
\hline Development of health literacy & $\begin{array}{l}\text { The sphere of physical training and } \\
\text { sports }\end{array}$ & 3.32 \\
\hline In-patient treatment & Municipal hospital & 3.31 \\
\hline $\begin{array}{l}\text { Scientific research in the sphere of prevention } \\
\text { of non-communicable diseases }\end{array}$ & $\begin{array}{l}\text { Medical education and research } \\
\text { organizations }\end{array}$ & 3.29 \\
\hline $\begin{array}{l}\text { Coordination of educational resources and } \\
\text { cooperation in the sphere of disease } \\
\text { prevention }\end{array}$ & Moscow City Pedagogical University & 3.29 \\
\hline Preventive health check-ups & Children's municipal polyclinic & 3.29 \\
\hline Integration of disease prevention resources & $\begin{array}{l}\text { Interdistrict Board of School } \\
\text { Principals }\end{array}$ & 3.26 \\
\hline $\begin{array}{l}\text { Bringing forward expectations related to the } \\
\text { quality of education in the sphere of } \\
\text { developing health literacy }\end{array}$ & Family & 3.2 \\
\hline Initiating health-related projects & $\begin{array}{l}\text { Interdistrict Board of School } \\
\text { Principals }\end{array}$ & 3.17 \\
\hline
\end{tabular}




\begin{tabular}{|c|c|c|}
\hline Extracurricular and educational activities & School & 3.17 \\
\hline $\begin{array}{l}\text { Clear goals and objectives in the sphere of } \\
\text { preserving health and developing health } \\
\text { literacy }\end{array}$ & $\begin{array}{l}\text { Department of Education and Science } \\
\text { of the City of Moscow }\end{array}$ & 3.14 \\
\hline Development of health literacy & School & 3.14 \\
\hline $\begin{array}{l}\text { Consulting (in the sphere of health in } \\
\text { education and development of health culture) }\end{array}$ & Moscow City Pedagogical University & 3.14 \\
\hline $\begin{array}{l}\text { Responsibility for the development of health } \\
\text { literacy }\end{array}$ & Family & 3.11 \\
\hline Control and protection of rights & Prosecutor's office and courts & 3.09 \\
\hline Development of health literacy & $\begin{array}{l}\text { Medical education and research } \\
\text { organizations }\end{array}$ & 3.09 \\
\hline $\begin{array}{l}\text { Initiating projects on preservation and } \\
\text { promotion of health }\end{array}$ & $\begin{array}{l}\text { Non-governmental organizations } \\
\text { within the system of the Department } \\
\text { of Education and Science of the City } \\
\text { of Moscow }\end{array}$ & 3.09 \\
\hline Consolidation and transmission of experience & $\begin{array}{l}\text { Interdistrict Board of School } \\
\text { Principals }\end{array}$ & 3.06 \\
\hline Technological support of medical classes & $\begin{array}{l}\text { Scientific and technical manufacturing } \\
\text { companies in the healthcare segment }\end{array}$ & 3.06 \\
\hline $\begin{array}{l}\text { Health preservation as a strategic benchmark } \\
\text { in Moscow education }\end{array}$ & $\begin{array}{l}\text { Department of Education and Science } \\
\text { of the City of Moscow }\end{array}$ & 3.03 \\
\hline Development of health literacy & $\begin{array}{l}\text { Non-governmental organizations } \\
\text { within the system of the Department } \\
\text { of Education and Science of the City } \\
\text { of Moscow }\end{array}$ & 3.03 \\
\hline Public control and inspection & $\begin{array}{l}\text { Non-governmental organizations } \\
\text { within the system of the Department } \\
\text { of Education and Science of the City } \\
\text { of Moscow }\end{array}$ & 3.03 \\
\hline $\begin{array}{l}\text { Differentiation between the sport of records } \\
\text { and the culture of safe physical development }\end{array}$ & Sphere of physical training and sports & 3.03 \\
\hline Innovative products and technologies & $\begin{array}{l}\text { Scientific and technical manufacturing } \\
\text { companies in the healthcare segment }\end{array}$ & 2.94 \\
\hline Development of health literacy & $\begin{array}{l}\text { Rospotrebnadzor (Federal State- } \\
\text { Funded Healthcare Institution "Center } \\
\text { for Hygienic Education of the } \\
\text { Population") }\end{array}$ & 2.91 \\
\hline Medical advice & Municipal hospital & 2.83 \\
\hline $\begin{array}{l}\text { Coordination of activities carried out by local } \\
\text { disease prevention institutions }\end{array}$ & Local self-government authorities & 2.82 \\
\hline Development of health literacy & Clinics & 2.79 \\
\hline Disease prevention work in health centers & Children's municipal polyclinic & 2.76 \\
\hline $\begin{array}{l}\text { Laboratory and technical support of disease } \\
\text { prevention activities }\end{array}$ & $\begin{array}{l}\text { Scientific and technical manufacturing } \\
\text { companies in the healthcare segment }\end{array}$ & 2.68 \\
\hline
\end{tabular}




\begin{tabular}{|l|l|l|l|}
\hline \multicolumn{2}{|l|}{ Development of health literacy } & Children's municipal polyclinic & 2.43 \\
\hline Exercise therapy & Children's municipal polyclinic & 2.35 \\
\hline \multicolumn{2}{|l|}{ Development of health literacy } & Municipal hospital & 2.31 \\
\hline $3.8-4.3$ & $3.3-3.8$ & $2.8-3.3$ & $2.3-2.8$ \\
\end{tabular}

The highest number of "unsatisfactory" ratings were assigned to the following categories: Interdistrict Board of School Principals - consolidation and transmission of experience (37.1\%); Rospotrebnadzor - information and awareness-raising events (40\%); prosecutor's office and courts - control and protection of rights (34.3\%); Moscow City Pedagogical University - consulting in the sphere of health literacy formation $(34.3 \%)$; children's municipal polyclinic - information and awareness-raising events $(60 \%)$, exercise therapy (55.9\%), health centers $(44.1 \%)$; municipal hospital - information and awareness-raising events $(60 \%)$ and medical advice (40\%); clinics - information and awareness-raising events (38.2\%); non-governmental organizations within the system of the Department of Education and Science of the City of Moscow - initiating projects on preservation and promotion of health (40\%), information and awareness-raising events and public control (37.1\% each); scientific and technical manufacturing companies in the healthcare segment - laboratory and technical support of disease prevention activities (47.1\%); family - responsibility for development of health literacy (34.3\%); physical ducation and sport - differentiation between the sport of records and the culture of safe physical development $(31.4 \%)$; prefectures and municipal councils - coordination of activities at the local level $(41.2 \%)$.

It was found that the experts assigned an extremely low consistent rating to the information and awareness-raising efforts, which lowers the overall evaluation of the work conducted by institutions and sectors to a great extent. High values were not assigned to any of the functions; therefore, the respective group is missing.

\section{Discussion}

Medium-high values were assigned to functions connected with covering vital needs, such as emergency care, prevention of communicable diseases, and sanitary requirements. In the context of social determinants of health, the readiness of the healthcare system for protecting the health of the whole society is important [6]. Expert reviews have proved that state healthcare is a crucial component of health infrastructure [1]. However, the Moscow healthcare system gained low ranks due to poor disease prevention functions [7].

Medium values were assigned to medical organizations, the sphere of physical education and sport, local self-government authorities in terms of implementation of the economic and communal functions, family as the party interested in the creation of safe learning and development conditions, and Moscow City Pedagogical University, which carries out educational and research projects. Today we may witness a strong impact on the research partnership communities in the social or medical services spheres, promotion of health literacy, and well-being of urban communities $[8,9]$.

An extensive number of functions performed by heterogeneous networking interactions in the field of disease prevention received medium-low expert ratings. Based on the results of comparative analysis of expert evaluation data, we made the following observations accurately correlating with the data obtained earlier $[5,10]$ :

- formalization of activities - formal functions standardized by regulations (control of compliance with health legislation, school safety, emergency health services, etc.), which are controlled by clear assessment criteria (case investigation, the rate of accidents and injuries, etc.), received higher ratings; 
- mono-/poly-subjectivity - mono-subject activities, where the person/institution in charge is clearly defined (creating the conditions for physical exercise, compliance with learning schedule, etc.) were ranked higher, while activities with distributed responsibility (creating the conditions for health promotion and observation, meal arrangements, development of health literacy, etc.) received extremely low values;

- organizational and managerial/substantive activities - the highest values were assigned to the substantive directions, and medium-low ones were received by infrastructure organization and management, where inter-institutional contexts arise.

The key result is an illustration of extremely low ratings assigned to the information and awareness-raising work, which is one of the essential aspects of all sectors without exception. The key result is to focus researchers on the underrated informing and awareness-raising work, which are the essential aspects of all sectors without exception. According to a few research works, lifelong teaching health literacy with educational means is a very important and relevant task [11-14]. In this context, school, which in line with its principal purpose carries out educational and forming work, looks favorable [15].

\section{Conclusion}

The organization of inter-institutional interaction of all sectors comprising the city health infrastructure is of primary importance. It is also necessary to provide continuous development of lifelong health literacy, which requires incorporating city online platforms, universities, and companies into the holistic urban health literacy system. Educational centers can systematically help to form health literacy, as they are local socio-cultural center points, that involve in educational activities both students and other residents of districts. However, without the active participation of healthcare and compliance with the requirements outlined in regulations, all efforts will have limited effect and will not lead to citizens' health promotion and health literacy improvement.

\section{References}

1. K.B. DeSalvo, Y.C. Wang, A. Harris, J. Auerbach, D. Koo, P. O'Carroll, Prev Chronic Dis, 14, 170017 (2017). http://dx.doi.org/10.5888/pcd14.170017

2. E.V. Nekhorosheva, Vestnik Moskovskogo Gorodskogo Pedagogicheskogo Universiteta. Seriya Ekonomika, 24(2), 110-117 (2020). http://dx.doi.org/10.25688/2312-6647.2020.24.2.11

3. B.A. Israel, A.J. Schulz, E. Parker, A. Becker, Annual Review of Public Health, 19, 173-202 (1998). https://doi.org/10.1146/annurev.publhealth.19.1.173

4. S. Roussos, S.B. Fawcett, Annual Review of Public Health, 21, 369-402 (2000). https://doi.org/10.1146/annurev.publhealth.21.1.369

5. R.A. Hogg, D. Varda, Health Affairs, 35 (11) (2016). https://doi.org/10.1377/hlthaff.2016.0725

6. G.C. Benjamin, Pan American Journal of Public Health, 35(11), 44 (2020). Accessed on: December 16, 2020. [Online]. Available: https://iris.paho.org/handle/10665.2/52233

7. E.V. Usova, M.V. Popovich, A.V. Manshina, V.A. Zinovieva, E.S. Danilova, I.S. Glazunov, E.I. Zabina, Profilakticheskaya meditsina, 20(6), 41-45 (2017). https://doi.org/10.17116/profmed201720641-45 
8. M. Currie, G. King, P. Rosenbaum, M. Law, M. Kertoy, J. Specht, Evaluation and Program Planning, 28(4), 400-412 (2005).

https://doi.org/10.1016/j.evalprogplan.2005.07.004

9. W. Majee, L. Goodman, M. Vetter-Smith, S. Canfield, Community Development, 47(1), 91-105 (2016) Accessed on: December 16, 2020. [Online]. Available: http://hdl.handle.net/10.1080/15575330.2015.1100643

10. M.K. Hamer, G.P. Mays, American Journal of Public Health, 110(S2), S232-S234 (2020). https://doi.org/10.2105/AJPH.2020.305694

11. L.T. Benuto, J. Casas, F. Gonzalez, R. Newlands, Community Ment Health J, 56, 1275-1283 (2020). https://doi.org/10.1007/s10597-020-00601-y

12. D. Levin-Zamir, D. Lemish, R. Gofin, Health Education Research, 26(2), 323-335 (2011). https://doi.org/10.1093/her/cyr007

13. H.T. Maindal, J. Aagaard-Hansen, Global Health Action, 13(1) (2020). https://doi.org/10.1080/16549716.2020.1775063

14. L.A. Denisov, E.V. Nekhorosheva, V.G. Avramenko, Sanitarny Vrach, 2, 47-56 (2020)

15. K. Dadaczynski, B.B. Jensen, N.G. Viig, M. Sormunen, J. von Seelen, V. Kuchma, T. Vilaca, Health Education, 120(1), 11-19 (2020). https://doi.org/10.1108/HE-12-20190058 